\title{
THE ROLE OF LOCAL STUDIES IN TRAINING OF STUDENTS OF ARTISTIC SPECIALITIES
}

\section{Prokopchuk V. I.}

\section{INTRODUCTION}

After declaring the independence research processes of true pages of history of our state and revival of cultural, historical and artistic memory of Ukrainian people have started. Interest in culture, history, artistic heritage and everything dealt with origins has become increasingly involved.

Nowadays there is an urgent need to preserve the independence of Ukraine against the backdrop of active social-cultural and socio-political processes. The modernization of modern Ukrainian school in particular high school and its integration into the European educational space exacerbated the problem of preservation of cultural identity and national character of Ukrainian people. Instilling of patriotism, national consciousness and dignity, preservation of cultural and artistic heritage, respect for customs and traditions of Ukrainian people, including artistic ones are strategic tasks of the national priority in this context.

Local history studies, particularly cultural and artistic in this culturalhistorical and artistic research through the prism of thinking and learning from the experience is very important. The regional approach and local history subjects play the significant role in the system of education of Ukraine especially in the direction of artistic local studies.

The education of national consciousness of young people as a future nation and knowledge, preserving of artistic heritage and cultural traditions must take regional approach and local history studies.

Prominent teachers and Ukrainian cultural figures such as N. Alchevska, G. Vaschenko, B. Grinchenko, M. Hrushevsky, M. Dragomanov, O. Duhnovych, P. Kulish, A. Makarenko, S. Rusova, G. Skovoroda, M. Stelmakhovych, V. Sykhomlynsky, L. Ukrainka, K. Ushynsky, I. Ffanko, P. Chubynsky, D. Yavornytsky created the foundation for ethnic studies, ethnopedagogics and scientific regional studies. 
Methodical fundamentals of local studies in the educational system, forms and methods of regional studies work were studied by such scientists as A. Aptikiev, I. Bezkorovainy, O. Dibrov, Y. Zhupansky, F. Zastavny, P. Ivanov, M. Kostrytsia, M. Krachylo, A. Lamashev, V. Matiyash, T. Mischenko, B. Naumov, V. Obozny, N. Pobirchenko, V. Prokopchuk, O. Savchenko, L. Smirnova, I. Sokolov, P. Tronko, O. Shamray, F. Shevchenko and others. Local studies was considered as an important part of teaching and educational process by these outstanding scientists.

Other research directions of local studies of Volyn region are focused on. Historical local studies was explored by L. Bazhenov, O. Bulyga, G. Buchalo, M. Danilicheva， G. Danylchuk， M. Manko, B. Pryschepa, O. Pryschepa, I. Yarmoshyk and others. Literary local studies of Volyn was studied by G. Demyanchuk, I. Nagorna, I. Paschuk, T. Ponamaryova and others. Different cultural artistic aspects of Volyn are introduced in researches such authors as M. Bendiuk, V. Luts, V. Kovalchuk, I. KulishLukashevych, O. Oshurkevych, T. Parkhomenko, O. Semenovych, B. Stoliarchuk, N. Suprun, R. Tyshkevych, A. Ukrainets, M. Fedoryshyn, R. Tsapun, S. Shevchuk and others.

Systematic studying of art local studies as a synthesized and holistic phenomenon of Ukrainian region of Volyn has not been submitted by scientists yet.

\section{Art local studies as a scientific problem}

Local studies is a treasure of age-old traditions, historical experience of generations and national-cultural memory. Past, present and future is combined by the melody of folk song and native language. Art local studies explores the origins of

Ukrainian mentality and spirituality. The formation of imagination about the fate of nation, development of patriotic and national consciousness is through the study of culture and history of "little homie".

The prominent Ukrainian educators, studying the cultural-artistic heritage of Ukrainian people (G. Vaschenko, A. Makarenko, S. Rusova, M. Stelmachovych, V. Sykhomlynsky, K. Ushynsky) emphasized the importance of local studies component in education and training of young generation.

G. Vaschenko who is a maker of Ukrainian national pedagogy created the image of educational ideal in his book "Educational ideal" based on the principles of Christian morality and spirituality. The scientist builds 
upon educational tradition of Ukrainian people and ethnopedagogy. G. Vaschenko is synthesis of common human and national ${ }^{1}$.

The concept of Ukrainian national educational system takes the central place in pedagogical heritage of S. Rusova. Native language and art (firstly national then world), national holidays and rites were considered the basis of education. S. Rusova said that nationally conscious child can grow up among native songs and nation is born next to heirloom crib only on the Mother Earth ${ }^{2}$.

The essence and traditions of folk pedagogy, its connection with history and culture were revealed in training manual for teachers "Folk pedagogy" by M. Stelmakhovych. Ukrainian ethnographic and folk materials were used in this book. M. Stelmakhovych initiated the study of Ukrainian ethnology and movement for revival and development of authentic Ukrainian pedagogy and school. The teacher believed national holidays, art, crafts, customs and rites to be the main means of aesthetic education. The pedagogical possibilities of local studies and folklore capacity are endless ${ }^{3}$.

V. Sykhomlynsky was convinced that people make the system of ethnic values which reflects the national consciousness through their language, folklore, traditions and art. The educator considered that the child can become a real human being and a true patriot doing the walk with the teacher from love for native land to understanding of historical destiny of all peoples of the world ${ }^{4}$.

K. Ushunsky who is the founder of Ukrainian national school considered local studies to be a powerful way of historical knowing and national character of people. He laid the foundations for school course "Motherland history" for primary schools of Ukraine. The school course was aimed to show the history and cultural folk customs and traditions. K. Ushunsky recommended to study school subject using the principal from similar and familiar (from native land) to distant and general (to the whole country). He also gave a great meaning to the development of children "instincts of locality" (ability to see the environment in the context of culture and society). K. Ushunsky was the first who

${ }^{1}$ Ващенко Г. Виховний ідеал. Полтава : Полтавський вісник, 1994. 191 с.

2 Калиниченко Н.П., Копиленко Н.Б. Софія Русова. Рідна школа. 1991. № 12. С. 69-72.

3 Стельмахович М.Г. Народна педагогіка. Київ : Радянська школа, 1985. $321 \mathrm{c}$.

4 Сухомлинський В.О. Сто порад учителеві: Вибрані твори : у 5 т. Київ, 1976. T. 2. C. 419-655. 
determined the local studies s a pedagogical phenomenon, emphasizing educational, pedagogical and social aspects 5 .

Local studies as a term of region or native land learning was first introduced in pedagogical science in 1914 by V. Ulanov who emphasized the importance of teacher's participation in the collecting of local studies materials and its using at lessons. The usefulness of creating the textbooks of local studies and a school regional museum as the necessity of introduction of local studies courses and workshops for teachers was determined ${ }^{6}$.

Local studies work was exposed in journals "Local studies", "Native land", "Culture and life". It was also described in scientific and educational literature. School methodologies promoted the local studies approach. The definitions of "local studies" and "history of Motherland" were proposed to delineate, but they were combined into a whole one because of uniformity and richness of work forms of the society ${ }^{7}$.

Local studies was included into the curriculum written by Kyiv provincial department of public education in 1919. The subject has been learned as a compulsory since 1920. The centre for the regional studies was founded in 1923 by the Ukrainian Academy of Sciences. The work of local studies commissions was lead by the centre for regional studies. All-Ukrainian local history conference held in 1925 was a great event for local studies development. Stocktaking of local history activity and starting of systematic work deals with concerted actions of newly created local history organizations for further coordinated work was the result of the conference ${ }^{8}$.

Regional museums, cultural educational and research centers coordinated regional studies work. But in the 1930s of the twentieth century all regional studies establishments were closed. The local studies work was stopped. Due to an order of 1932 "On training programs and

5 Ушинський К. Д. Твори в 6-ти томах. Київ : Радянська школа, 1995. Т. 6. C. 562-566.

${ }^{6}$ Морітз Я. Система професійної підготовки вчителя і шляхи іiї оптимізації в умовах розвитку сучасної освіти в Польщі : автореф. дис. ... док. пед. наук : 13.00.04. Київ, 2004. 41 с.

7 Анікіна Т.О., Таран Н.С. Науково-історичні передумови використання художнього краєзнавства у вихованні патріотизму. Педагогіка $i$ психологія. 1995. № 4. С. 98-105. С. 102.

8 Анікіна Т.О., Таран Н.С. Науково-історичні передумови використання художнього краєзнавства у вихованні патріотизму. Педагогіка $i$ психологія. 1995. № 4. C. 98-105. 
regime in secondary schools" regional studies did not become the basis of educational process, but only adjuvant means of education and upbringing.

As it is known the development of regional studies was impossible in Soviet times as a result of generally unified policy of socialistcommunist state strategy.

Local studies is a science which explores comprehensively a specific part of country or region. This is an interpretation of the encyclopedia ${ }^{9}$.

P. Tronko, the academician of the Ukrainian Academy of sciences gives three-in-one interpretation of "local studies": as a set of scientific disciplines differ as to content and particular as to research methods; integrated scientific research; scientific civil movement aimed at the popularization of knowledge to preserve historical and cultural local heritage to form national self-consciousness and dignity ${ }^{10}$.

School local studies is taken as learning of training manual or teacher's stories about culture, history and nature of the region ${ }^{11}$.

O. Shamrai considers school local studies as an effective way to formation of patriotic and national consciousness of young people and the source of knowledge about the present and the past of native region ${ }^{12}$.

Ukrainian historian, ethnographer and folklorist P. Ivanov introduced for the first time the term "pedagogical local studies" in 1966. The scientist emphasized the need to introduce the subject at local studies in higher education institutions. The importance of strengthening of local studies was justified by P. Ivanov. Pedagogical local studies was considered not as only training course, but as a field of pedagogy ${ }^{13}$.

The analysis of scientific-pedagogical literature suggests the implication of the existence of different definitions of "local studies", "school local studies" and "pedagogical local studies". The scientists describe «local studies» as "scientific memories", "civil moment", "method of research", "method of education", "didactic principle",

${ }^{9}$ Мала енциклопедія етнодержавознавства / ред. кол.: Ю.І. Римаренко (відп. ред.) та ін. Київ : Довіра : Генеза, 1996.942 с. С. 86-87.

${ }_{10}$ Тронько П.Т. Історичне краєзнавство: Крок у нове тисячоліття (Досвід. Проблеми. Перспективи). Київ, 2000. 270 с. С. 12.

${ }^{11}$ Педагогічний словник / за ред. М.Д. Яремченка. Київ : Педагогічна думка, 2001. 321 с. С. 269.

12 Шамрай О.Г. Роль краєзнавства у навчально-виховному процесі. Педагогічний вісник/ 2002. № 4. С. 73-75.

13 Иванов П. В. Педагогические основы школьного краеведения. Петрозаводск : Карел, 1966. 182 с. 
"scientific discipline", "controversial complex of disciplines", "form of extracurricular work".

This diversity of terminology and interpretation of these concepts are predetermined of insufficiently developed theoretical foundation and multidimensional nature of functions, such as: educational, pedagogical, scientific, cultural, developing, exploratory and socially useful. Pedagogical multifunctionality, interdisciplinarity, multidisciplinary, synthetics are the most characteristic features of integrated concept "local studies". The territory and national character are systematically important and unifying factors ${ }^{14}$.

According to the aims and tasks of research these are three forms of local studies: public (scientific), educational(school) and social. The main functions of local studies are pedagogical, learning and scientific. Local studies researchers have two forms of implementation of tasks. They are carried at the public and social levels.

According to substantive content there several directions in local studies. They are: historical, ethnographic, geographic, literary and artistic.

Artistic local studies is dedicated to the activity and creativity of figures of different spheres of art culture. Artistic local studies is divided into musical, ethnographic, theatrical. There is regional studies in the sphere of art, activities of art museums and architecture ${ }^{15}$.

The concept of "art culture" and "musical culture" was analyzed in philosophical and aesthetic and psychological aspects (M. Bahtin, I. Ziaziun, M. Kagan, O. Komaroska, L. Masol, N. Myropolska, G. Padalka, O. Rudnytska, O. Scholokova).

Musical culture covers achievements in the sphere of musical creativity, education and knowledge of musical $\operatorname{art}^{16}$.

Art culture is defined as a combination of phenomenon and process of spiritual and practical activities of people, who perceive, create and

${ }^{14}$ Прокопчук (Дикало) В.I. Мистецьке краєзнавство як науково-педагогічна проблема. Інноватика у вихованні : зб. наук. праць / упоряд. О.Б. Петренко ; ред. кол. : О.Б. Петренко, Р.Л. Сойчук, Т.С. Ціпан та ін. Рівне : РДГУ, 2019. Випуск 10. С. 226-233. DOI : 10.35619/iiu.v1i10.189. С. 227-229.

15 Прокопчук (Дикало) В.І. Законодавче забезпечення розвитку мистецького краєзнавства в Україні. Нова педагогічна думка : наук.-метод. журнал. Рівне : POІППО, 2019. № 4(100). С. 181-185. DOI : 10.37026/2520-6427-2019-100-4181-185. С. 124.

${ }^{16}$ Юцевич Ю.С. Музика. Словник-довідник. Тернопіль : Навчальна книга Богдан, 2003. 352 с. С. 131. 
disseminate the work of art and things of aesthetic values, characterise, tastes and preferences of society. Art culture is multifunctional and it has local culture character due to the influence on the personality ${ }^{17}$.

Taking into account the term "artistic culture" as an original category with its content and form is very important due to historical fate and national peculiarities of people. Knowledge of works of art and understanding their influence on the personality is possible if there is a deep cognition of historical-ethnic origins of nation. Thus, art culture is one of the components of national culture ${ }^{18}$.

Art local studies detects and analyze the cultural progress of region and nation. It gives the opportunity to understand cultural-educational priorities and problems interpret and reconstruct the content of art values of the past and modern works of art.

Art local studies is included into the system of local studies sciences. Musical local studies is its component. Musical local studies explores musical culture of region or city with the purpose of defining characteristic and patterns of its creation, functioning and development ${ }^{19}$.

B. Asafyev at the time considered musical local studies as a part of music science and local study section ${ }^{20}$.

From Etinger's point of view the essence of musical local studies was seen in entity of phenomenon of musical local culture and using the knowledge in educational process ${ }^{21}$.

The researcher of Ukrainian musical folklore V. Gubyak points out that "Local study folklore of native land is a rescue in the educational process of students and healing the wounds of our mindlessness" ${ }^{\prime 22}$.

The whole historical cultural way of Ukrainian people is reflected in highly poetic and deply lyrical forms of folklore, including artistic one. It is the most important part of ethnopedagogics. It is also an integral part

17 Рудницька О.П. Педагогіка: загальна та мистецька : навчальний посібник. Тернопіль : Навчальна книга - Богдан, 2005. 360 с. С. 70-71.

${ }^{18}$ Рудницька О.П. Педагогіка: загальна та мистецька : навчальний посібник. Тернопіль : Навчальна книга - Богдан, 2005. 360 с. С. 52-53.

${ }^{19}$ Юцевич Ю.С. Музика. Словник-довідник. Тернопіль : Навчальна книга Богдан, 2003. 352 с. С. 167.

${ }^{20}$ Асафьев Б.В. Русская музыка ХІХ и начала XX века. 2-е изд. Ленинград, 1979. $340 \mathrm{c.}$

21 Этингер М. Внимание к музыкальному краеведению. Советская музыка. 1983. № 1. С. 99-102.

22 Губ'як В.Д. Виховання учнів на засадах народної творчості і фольклору. Рідна школа. 1999. № 11. С. 9-11. С. 9. 
of national educational system. Musical folklore, artistic folklore traditions, customs and rites are great and deep educational potential. Youth becomes an integral part of cultural artistic and aesthetic-spiritual life of their nation and state studying in practice musical traditions and art. Local history plays a leading role in formation of spirituality and national education of youth ${ }^{23}$.

Musical local art is reviewed from two aspects: as a scientific field and academy discipline. Musical art as a scientific field explores the content of musical culture of native land in local history aspect ${ }^{24}$.

The need for the introduction of the course "Musical local studies of Rivne region" for the training of students of artistic specialities is determined by necessity of solving state tasks and demands of society for professional specialist training and to be competent in ethnocultural processes of Ukraine.

The formation of musical culture as an integral part of historical cultural processes of native region is a subject of musical local studies.

Specific phenomena of musical culture of native region of the past and present such as creativity of artists, content and forms of musical education, life forms of musical art in the context of artistic culture is the subject of musical local studies.

Principles of historicism, unity of national cross-cultural, dialectics of individual and general, systematic, cultural relevance, tolerance, respect for cultural diversity, unity of tradition and innovation, the interaction between theoretical and practical mastery of education and culture are the dominant principles of musical local studies.

The art of Rivne is seen as the art of historical ethnographic region of Volyn. It has developed under the influence of cultural interaction of Ukrainian and other ethnic groups. They lived on the areas of origin. The Poles, The Germans, The Czechs and the Jews were the most numerous. The research of local art specifity in the aspect of musical local studies is very important for better understanding of cultural artistic process of Ukraine $^{25}$.

${ }^{23}$ Основи національного виховання: концептуальні положення / В.Г. Кузь, Ю.Д. Руденко, 3.О. Сергійчук та ін. Умань, 1993. 112 с.

${ }_{24}$ Дикало В. Музичне краєзнавство Рівненщини як навчальний курс: до постановки проблеми. Нова педагогічна думка : наук.-метод. журнал. 2016. № 2(86). C. 124-128. C. 124.

25 Дикало В. Музичне краєзнавство Рівненщини як навчальний курс: до постановки проблеми. Нова педагогічна думка : наук.-метод. журнал. 2016. № 2(86). C. 124-128. C. 125. 
Course content focuses upon the musical component of local culture. It also covers other kinds of art such as choreography, theatre (performing arts), fine art and demonstrates the logic of Ukrainian art processes in space and time.

The innovation of the course is in consistent content implementation. The course combines music science and local studies, focuses student's attention on using knowledge gained in future professional activity.

The aim of the training course is to introduce musical culture of Rivne region using the methods and techniques of local studies. Local sciences are aimed to form a system of professional student's competence future teachers of music researchers and propagandists of local culture ${ }^{26}$.

The tasks of the course are to improve the professional pedagogical competence and knowledge of local musical culture in the context of development of Ukrainian culture in historical cross-cultural context. The course is aimed to the education of national consciousness, patriotic and value attitude to local culture and students training in future pedagogical activity for learning, development and spreading local cultural traditions.

The resource base of the course consists of country's and international documents on national-patriotic educations by means of national cultural heritage, local studies development and the development of national minorities in Ukraine. The documents which give the opportunities to explore the formation of musical culture of Volyn region in the context of general Ukrainian process in historical retrospective are included. Thesis researchers devoted to the development of musical culture and education of Volyn, scientific resources of Volyn, education history, musical aesthetic, art history, historical and local studies literature, encyclopedia and reference material documents of the fund of the State Archives of Rivne region and museums. Periodical publications, posters, programmes of concerts, materials about modern musical groups, composers, musicians, historians and others are involved in the creation of art-cultural space of Rivne and Volyn regions.

Scientific methodological approaches to content organization of the course are determined by the author:

26 Дикало В. Музичне краєзнавство Рівненщини як навчальний курс: до постановки проблеми. Нова педагогічна думка : наук.-метод. журнал. 2016. № 2(86). С. 124-128. C. 125-126. 
- multiartistic: musical local studies must be realized by the students as an integral part of art local studies according to the unity of artistic culture. It is important to note, that musical local studies for other types of art (theatre, choreography, architecture, fine art) are studied as the components of art: folklore ethnographer folk) and academic (classical, professional);

- cultural: Musical culture o Volyn as Rivne region is considered not as a holistic context of musical culture of Volyn, but also as an integral part of cultural musical processes of Ukraine;

- multiethnic: According to this approach the culture of Rivne region is considered as multiethnic in harmonious unity of culture of ethnic groups and peoples in a single cultural space of Ukraine. In this context Rivne region is multiethnic cultural region, where artistic heritage of each ethnic group enriches a holistic culture of native land. It is important to note, that such scientific methodological approach is logically transformed in the culture of every region of Ukraine. So it is harmonious for the whole multi-ethnic Ukrainian state, which consists of 100 ethnicities and nationalities ${ }^{27}$.

The course consists of three sections: I - theoretical basis of musical local studies; II - local science approach to studying of musical culture. Musical culture of Rivne region as a historical-ethnographic of Volyn; III - musical local studies as a ground of Art local studies.

The first section reviews Volyn as one of the biggest historicalethnographic regions of Ukraine. Pedagogical aspects of local studies of the famous Ukrainian educators are being explored. Students acquainted with the history and the process of formation of Rivne Local Studies. The activity of the first Ukrainian local science organizations, National Community of historians of Ukraine, a society of Rivne region ethnographers, and activity of outstanding ethnographers of the past and modern of native land are described in the first section.

The second section outlines Volyn as a multi-ethnic cultural region of Ukraine. The oldest and the most numerous ethnic groups of Volyn and Rivne regions (the Poles, the Germans, the Czechs, the Jews) and their musical folklore and culture are presented in this section. The activity of cultural educational society of ethnic groups is described. The legislative support of the development of national minority culture in Ukraine

27 Дикало В. Музичне краєзнавство Рівненщини як навчальний курс: до постановки проблеми. Нова педагогічна думка : наук.-метод. журнал. 2016. № 2(86). С. 124-128. С. 126. 
which is very relevant in the context of multi-ethnic Ukrainian state is represented. Local and academic musical traditions, sacred and pop musical culture are examined in the second section.

Theatrical and choreographic art of Volyn and the features of Art of Rivne, monuments of architecture and the peculiarities of local museums are introduced for studies in the third section. The topic of the third chapter is "Music is in the system of other arts". It is very important. Art and artistic culture are determined as unbroken unity and interconnection. Types of art, genres of art, functions of art and classifications, the birth of art, its synthesis and multifunctionality are connected ${ }^{28}$.

Teaching methodologies involves traditional forms of work (lectures, discussions, practical classes, individual and creative tasks, scientific projections, reviews of musical compositions) and experience local culture (excursions in the museums, attending concerts, folklore practice).

Research activities of the students (folklore collecting, searching for folklore books, historical works and publications about ethnographers and artists of the region) provides the creativity of the lessons and cognitive interest in studying of the course is an integral concept of the course.

\section{State support for the development of artistic local studies in Ukraine}

Legislative support of local studies in particular artistic local studies as a national spiritual treasure is a basis of its successful development. The independence of Ukraine is aimed at national culture revival and returning to the national and regional basics. Favorable conditions for the development of local studies were created.

All-Ukrainian Union of ethnographers was established on 27 March, 1990. It became a local point of ethnographic work in Ukraine. The revival of local history has started. National Union was established as a rightful heir of Ukrainian Committee of local history. It was repressed in the 1930 s in conditions of political terror and active creating of totalitarian system of government.

On 16 October, 2008 All-Ukrainian Union of ethnographers obtained the status of National Union of ethnographers of Ukraine and combined local researchers. The Union encourages sense of patriotism and national

28 Дикало В. Музичне краєзнавство Рівненщини як навчальний курс: до постановки проблеми. Нова педагогічна думка : наук.-метод. журнал. 2016. № 2(86). С. 124-128. 
identity, deep respect for Ukrainian history, language, culture, traditions, customs and other ethnic groups and nations connected with Ukraine ${ }^{29}$.

The main goal of the Union is the development of national local studies and involvement of various sectors of the population (amateurs and professionals) in studying of native land, creating the popular science and documentary works on history and local culture using gained experience in this field not only in Ukraine, but outside it.

National Union of ethnographers cooperates with public authorities, government, scientific-research institutions, cultural and educational facilities, social organizations and political parties of Ukraine. It also collaborates with foreign research institutions and Ukrainian diaspore. They are interested in preserving national historical and cultural heritage of Ukrainian people, cultural artistic uniqueness ${ }^{30}$.

The main activity of the Union is cultural artistic. It includes research -creative activity in the field of culture, examination of the past and modern cultural development of cities and regions, experience of academic and cultural institutions. Identification, research and preserving the properties of material and spiritual culture. Search and returning in Ukraine the properties of national cultural heritage, participation in creating of All-Ukrainian and regional studies programmes and projects are the main tasks of the Union. Development of international-cultural contacts, cooperation with international, cultural international institutions, organizing conducting of cultural educational event, artistic events, exhibitions, thematic meetings, revival, development and popularization of folk art, traditions and rites, preserving and enrichment of the heritage, development of respect for historical cultural values, Ukrainian traditions, assistance to educational work are the core aspects of the work of National Union of ethnographers ${ }^{31}$.

29 Національна спілка краєзнавців України. URL : http://nsku.org.ua/? page_id=5610 (дата звернення 15.02.2020); Прокопчук (Дикало) B. I. Законодавче забезпечення розвитку мистецького краєзнавства в Україні. Нова педагогічна думка : наук.-метод. журнал. Рівне : РОІППО, 2019. № 4 (100). C. 181-185. DOI : 10.37026/2520-6427-2019-100-4-181-185.

30 Національна спілка краєзнавців України. URL : http://nsku.org.ua/ ?page_id=5610 (дата звернення:15.02.2020).

31- Національна спілка краєзнавців України. URL : http://nsku.org.ua/ ?page_id=5610 (дата звернення 15.02.2020); Прокопчук (Дикало) B.I. Законодавче забезпечення розвитку мистецького краєзнавства в Україні. Нова педагогічна думка : наук.-метод. журнал. Рівне : РОІППО, 2019. № 4(100). C. 181-185. DOI: 10.37026/2520-6427-2019-100-4-181-185. 
The Union was a co-organizer of government programme "Returned names". The programme was developed in 1992 by National commission to a Cabinet of Ministers on returning cultural properties to Ukraine. The goal of the programme was to carry out of scientific and educational events aimed at returning the heritage and creative achievements of outstanding and cultural figures as scientific-cultural properties of Ukraine $^{32}$.

The independence of Ukraine has enabled success to prohibited archive sources and literature, works of Ukrainian people in Diaspora. New facts about unreported historical-cultural events of the past were revealed. New possibilities for rapid development of local studies were created. Ethnographic institutions and centres were established for holding of international symposiums and congresses, All-Ukrainian and regional scientific-ethnographic expeditions and conferences. Substantive studying of cities and regions, exploring of unreported historical events, activity and life of outstanding but forgotten figures, realization of ethnographic projects, increase in publishing of ethnographic-historical works were started. A set of scientific documentary works "Rehabilitated by history", "Repressed local studies" and historical-memorial works "Books of memory of Ukraine", "Books of grief" were published. Such State institutions as The Institute of History of Ukraine of the Ukrainian Academy of Sciences, the National Academy of Pedagogical Sciences of Ukraine, Ukrainian Conservation Society of historical and cultural sights, the Junior Academy of Sciences of Ukraine, Ukrainian Cultural Foundation, museums, organizations of National unions, libraries, educational establishments and other ethnographic centers joined the national process of scientific research activity.

Active development of local studies and increasing the number of researches of historical cultural traditions has created a need for providing national legislative support of these processes for their regulation and further successful development.

Local studies is maintained by legal state acts. The legislative acts determine strategic directions of the developments of local studies. The Decree of the President of Ukraine "Decree on measures to support local studies in Ukraine" instructed to provide the development of local studies topics taking into account the peculiarities of regions of Ukraine

\footnotetext{
32 Державна програма «Повернуті імена» : Нац. комісія 3 питань повернення в Україну культурних цінностей. Київ : ООО «Танант», 1996. 26 с. 
and including in curriculums of general education schools, extracurricular and higher education institutions ${ }^{33}$.

"The program of development of local studies for the period up to 2010" was approved by the government. It involved teacher training and retraining, employees of cultural institutions on the basis of postgraduate pedagogical education institutes of Ministry of education of Ukraine to enhance the scientific and educational local studies activities ${ }^{34}$.

"The program of development of local studies for the period up to 2010" was implemented thanks to selfless work of regional organizations, scientists and activists of local studies. So a number of tasks have not been solved.

"Draft State programme of development of local studies for the period up to 2025 " is designed. The main tasks of the draft are the development of branch directions of local studies, including culturalartistic one, opening the departments of local studies in educational institutions, providing general and higher education institutions with local studies methodical literature. Strengthening of local studies capacity in educational system and introduction local studies into the training programs, government officials and cultural workers are also major tasks of the Draft ${ }^{35}$.

Local studies component in the educational process is emphasized in Concept (author L. Masol) and in Comprehensive program of artistic and aesthetic education of students of secondary education institutions and extra-curricular institutions. Mastering a regional culture and art, using of educational potential of artistic and aesthetic environment are very important. It is also noted that art which combines universal, national (state) and regional (local studies) components is effective means of patriotic education. Art conveys value attitudes to the world through the prism of ethno-national specificity and non-verbal dialogue of cultures ${ }^{36}$.

33 Про заходи щодо підтримки краєзнавчого руху в Україні : Указ Президента України від 23.01.2001 р. № 35/2001. URL : http://zakon2.rada.gov.ua/ laws/show/35/2001 (дата звернення: 25.01.2020).

34 Про затвердження Програми розвитку краєзнавства на період до 2010 року : Постанова КМУ від 10.06.2002 р. № 789. URL : http://zakon4.rada.gov.ua/ laws/show/789-2002-\%D0\%BF (дата звернення: 15.02.2020).

35 Перспективи розвитку краєзнавчого руху: пропозиції до проекту Державної програми розвитку краєзнавства на період до 2025 p. URL : http://history.org.ua/JournALL/kraj/kraj_2013_1/2.pdf_ (дата звернення: 15.02.2020).

36 Концепція та комплексна програма художньо-естетичного виховання у загальноосвітніх та позашкільних навчальних закладах : Інформ. збірник 
Education of young people by means of national cultural artistic heritage is very relevant at the international level. Convention "On protection of the intangible cultural heritage", "On protection and promotion the diversity of cultural expressions" focuses on formation of society in Ukraine with harmonious development and interaction of different ethnic groups. It creates an atmosphere of interethnic tolerance, national unity, fostering respect for culture, history, language and traditions of different ethnic groups ${ }^{37,38}$.

The Decree of the President of Ukraine "On reproduction measures of recreation of outstanding sights of history and culture" was issued to revive cultural historical-architectural and artistic heritage of Ukrainian people. It is a unique cultural value ${ }^{39}$.

All-Ukrainian action of youth labor detachments "Save and revive cultural heritage of Ukraine" was held in June 2008 by the Ministry of family, youth and sports as a part of the program of local studies development and involving young people in preserving cultural sights and landmarks of the region. Lutsk castle, the Museum of Folk architecture and life in Pirogovo, historical cultural complex "Zaporizhian Sich" on Hortytsia were ordered by the students during this action $^{40}$.

Intersectoral program "Learn your country" for 2007-2012 was approved by Cabinet of Ministers of Ukraine for the development of local studies in the direction of national patriotic education and popularization of cultural heritage of Ukrainian people among the youth. The program at involving young people in research local studies activity and cultural artistic events ${ }^{41}$.

М-ва освіти і науки України / Л.М. Масол, Н.І. Ганнусенко, О.А. Комаровська, С.А. Ничкало та ін. Київ : Пед. преса, 2004. № 10. 32 с.

37 Конвенція про охорону нематеріальної культурної спадщини від 06.03.2008 p. № 132-VI. URL : https://zakon.rada.gov.ua/laws/show/995_d69 (дата звернення: 15.02.2020).

38 Конвенція про охорону та заохочення розмаїття форм культурного самовираження. Ратифіковано Законом України від 20.01.2010 р. № 1811-VI. URL : http://zakon0.rada.gov.ua/laws/show/952_008 (дата звернення: 15.02.2020).

39 Про заходи щодо відтворення видатних пам'яток історії та культури : Указ Президента України від 9.12.1995 р. № 1138/95. URL : https://zakon.rada.gov.ua/laws/show/1138/95 (дата звернення: 25.01.2020).

${ }^{40}$ Молодіжні трудові загони відродять Батурин, Бахчисарай та Хортицю : Урядовий портал. URL : http://old.kmu.gov.ua/kmu/control/uk/publish/printable_ article?art_id=140533446 (дата звернення: 15.02.2020).

${ }^{41}$ Про затвердження Міжгалузевої програми «Пізнай свою країну» на 20072012 роки : Наказ Міністерства культури і туризму України, Міністерства 
It is important to note that one of the main tasks of Ukraine in the education, local studies, cultural and art sectors is national patriotic education of young generation. The main goal of national patriotic education is upbringing of patriot of Ukraine who is ready to inherit national cultural artistic heritage of the people. It is stated in such documents as "Concept of national patriotic education of children and young people for 2016-2010", The Law of Ukraine "About education", "National strategy of educational development of Ukraine for the period up to $2021,42,43,44,45$.

National patriotic education was considered the foundation of the whole system by outstanding teachers of the past: G. Vaschenko, O. Duhnovych, S. Rusova, V. Sykhomlynsky, K. Ushunsky and others. K. Ushunsky believed that every nation had its own national system of education ${ }^{46}$. A man who doesn't know his own national culture was named as "a man without a country" by K. Ushunsky. He considered that such man is not be able to build and maintain a friendly relationship with other peoples ${ }^{47}$. S. Rusova convinced that national education provides every nation with democratic education. National upbringing of young

освіти і науки України, Міністерства України у справах сім’ї, молоді та спорту, Державного комітету телебачення та радіомовлення України від 27.08.2007 р. № 49/765/3027/308. URL : https://zakon.rada.gov.ua/rada/show/v004965507/sp:max15 (дата звернення 15.02.2020).

42 Про затвердження Концепції національно-патріотичного виховання дітей i молоді, Заходів щодо реалізації Концепції національно-патріотичного виховання дітей і молоді та методичних рекомендацій щодо національнопатріотичного виховання у загальноосвітніх навчальних закладах : Наказ $\mathrm{MOH}$ України від 16.06.2015 р. № 641. URL : http://osvita.ua/legislation/Ser_osv/47154/ (дата звернення 25.01.2020).

${ }^{43}$ Прокопчук (Дикало) В.І. Мистецьке краєзнавство як чинник національнопатріотичного виховання майбутніх педагогів / Молодь і ринок : щуомісячний науково-педагогічний журнал. Дрогобич : Дрогобицький держ. педагог. університет ім. I. Франка, 2019. № 12 (179). С. 64-69. DOI: https://doi.org/10.24919/2308-4634.2019.193520.

44 Про Національну стратегію розвитку освіти в Україні на період до 2021 року: Указ Президента України від 25.06.2013 р. № 344/2013. URL : http://zakon3.rada.gov.ua/laws/show/344/2013 (дата звернення 15.02.2020).

45 Про освіту: Закон України від 16.01.2020 p. № 2145-VIII. URL : https://zakon.rada.gov.ua/laws/show/2145-19 (дата звернення 15.02.2020).

46 Основи національного виховання: концептуальні положення / В.Г. Кузь, Ю.Д. Руденко, 3.О. Сергійчук та ін. Умань, 1993. 112 с. С. 41.

47 Основи національного виховання: концептуальні положення / В.Г. Кузь, Ю.Д. Руденко, 3.О. Сергійчук та ін. Умань, 1993. 112 с. С. 39. 
generation nurtures respect for another people through respect for their people ${ }^{48}$.

Knowledge of the native land, city is passed down from generation to generation through folk song, customs, traditions and native language. Formation of patriotism, national consciousness and revival of historical memory is a significant component of this process. Studying the culture of native land encourages respect not only for its people, but also for ethnic groups and people who lived in Ukraine historically. So regional musical history plays a significant role in carrying out of the tasks.

The national idea in the education system is fundamental. Patriotic education provides the feeling of patriotism and understanding of civic duty. It is the basic component of national idea. National education provides for ethnicization of young people as an integral part of socialization. It is based on cultural-historical experience of the nationality, customs and traditions. National education is a reproduction of specific and human which is common for all nations of the world ${ }^{49}$.

Nurturing patriotism, respect of historical cultural traditions, cultural values and property of Ukrainian people are the foundations of public policy and the principles of educational activity and specified in the Law of Education of Ukraine ${ }^{50}$.

Sense of patriotism is considered the most important state task of educating of the young generation by modern scientists I. Bekh and K. Chorna. Patriotism is seen by authors as social and individual value, a component of personality structure, love for the motherland, willingness to defend it and share its fate. Scientists say that patriotism involves love and knowledge of features of their "homeland"51. It is very important in the context of professional training of students of artistic specialities by means of artistic musical local studies.

The goal of patriotic education is based on the principal of national direction, multicultural historical memory. It is being implemented through the formation of tolerant attitude to other peoples, cultures,

48 Основи національного виховання: концептуальні положення / В.Г. Кузь, Ю.Д. Руденко, 3.О. Сергійчук та ін. Умань, 1993. 112 с. С. 63.

49 Основи національного виховання: концептуальні положення / В.Г. Кузь, Ю.Д. Руденко, 3.О. Сергійчук та ін. Умань, 1993. 112 с.

50 Про освіту: Закон України від 16.01.2020 p. № 2145-VIII. URL : https://zakon.rada.gov.ua/laws/show/2145-19 (дата звернення: 15.02.2020).

51 Бех І. Д., Чорна К. І. Національна ідея в становленні громадянина-патріота України: (Програмно-виховний контекст). Черкаси, 2010. 40 с. С. 16-18. 
traditions, development of respect for cultural historical part of Ukraine $^{52}$.

It is in line with tasks and directions of activity of National Union of Ethnographers of Ukraine and it is reproduced in concept of the course "Musical local studies of Rivne region".

Decree of the President "About some urgent support measures for culture and spirituality in Ukraine" is very important for local studies development. It emphasizes on the necessity to support regional cultural initiatives and celebration of anniversaries and commemorative dates ${ }^{53}$.

The Decree is implemented in the publication of the annual artistic and educational guide "Significant and memorable dates". It has been published since 2015 by the department approval of playing musical instruments, by Academic Council, educational methodological commission of Institute of Arts of Rivne State University of Humanities (compilers: V. Procopchuk (Dykalo), M. Smalko, L. Yakovenko; science editor V. Prokopchuk). The guide is aimed at students and teachers of art educational institutions, cultural and art workers, social activists and ethnographers. It provides rational, effective early planning of work and informative support in preparation of cultural and educational activities, art projects actions ${ }^{54}$.

The guide includes anniversaries and memorable dates, which are very important for Rivne (Volyn region of Ukraine). The uniqueness of guide is also in the lists of anniversary dates, significant events of world importance. This publication fulfills not only the main purpose of National Union of Ethnographers of Ukraine but the main tasks of ethnographic projects, state legislative acts and The Decrees of the President of Ukraine on development of local studies, a half-centure initiative of the international organization UNESCO to commemorate the memorable dates and international holidays. Including anniversaries of

\footnotetext{
52 Про затвердження Концепції національно-патріотичного виховання дітей i молоді, Заходів щодо реалізації Концепції національно-патріотичного виховання дітей і молоді та методичних рекомендацій щодо національнопатріотичного виховання у загальноосвітніх навчальних закладах : Наказ МОН України від 16.06.2015 р. № 641. URL : http://osvita.ua/legislation/Ser_osv/47154/ (дата звернення 25.01.2020).

53 Про деякі невідкладні заходи щодо підтримки культури і духовності в Україні : Указ Президента України від 12.01.2009 р. № 6/2009. URL : https://zakon1.rada.gov.ua/cgi-bin/laws/main.cgi?nreg=6\%2F2009\&p= 1287560658798567 (дата звернення 25.01.2020).

54 Знаменні та пам'ятні дати 2015 року : мистецько-освітній довідник / упоряд. В.І. Дикало, М. Ф. Смалько, Л.П. Яковенко ; за ред. В.І. Дикало. Рівне : О. Зень, 2015. 76 с. С. 3-7.
} 
prominent figures and important events of Ukrainian people into special calendar of UNESCO for uniting people, states, nations and consolidation of peace in the world is very important.

The textbook "The basis of local studies" for the students of all specialities of higher educational institutions was written by National Union of Ethnographers of Ukraine. The main task of implementation of local studies course is to preserve the national nature of education, cultural-historical revival of Ukrainian people, education of patriotism, national dignity and consciousness 55 .

Introduction of the course "Musical local studies of Rivne region" is necessary for training future teachers of music, musical art, ethics, aesthetics and all artistic specialities is appropriate and indisputable. The relevance of the course is determined by the need for a solution of state tasks and needs of society for preserving ethno-regional values in the revival of national culture.

\section{CONCLUSIONS}

Musical art is very important for the development of musicalpedagogical and art education in particular for preparation of the students of all artistic specialities. In modern society, including art local studies, influences key processes in different spheres of social spiritual, political and cultural - artistic life of Ukrainian society. It is a very important factor of successful development.

Artistic local studies is a powerful factor of formation of patriotism and national consciousness. Nowadays it is a priority task to preserve cultural-artistic heritage in education, culture, art and local studies. It accomplishes the tasks of National Union of Ethnographers of Ukraine. The significance of artistic local studies is increasing. The processes of affirmation of personality culture, ethnic groups and nation are intensifying. The tendency of convergence and interpenetration of cultures including art and preserving the uniqueness and national identity is deepening.

Relevance and expediency of introducing educational course "Musical local studies of Rivne region" to higher educational institutions for training of teachers of music, musical art, art culture and all artistic specialities is necessary for solving of state tasks in the sphere of education and local studies for national patriotic education. Local studies approach in education is taken into account. Studying of specificity of musical culture of Rivne regions as a multiethnic historical-ethnographic

55 Національна спілка краєзнавців України. URL : http://nsku.org.ua/? page_id=5610 (дата звернення: 15.02 .2020 ). 
region of Volyn is important for understanding of holistic picture of cultural art and pedagogical processes. Local studies in Ukraine is supported at national and international level. It is very substantive for further successful development.

\section{SUMMARY}

The article is devoted to clarifying the role of artistic local studies for training of future teachers of music and in the system of the development of music - pedagogical education. Systemic view of all local studies as a holistic synthesized cultural phenomenon is introduced. The content of such concepts as "Local studies", "Musical local studies" as an important component of the system of local sciences is revealed. It is found out that musical local studies is a component of artistic local studies and a significant direction of national patriotic education. It is a strategic task in the development of Ukraine and in the educational training of the students of higher education institutions. The activity of National Union of Ethnographers of Ukraine as a focal point of regional studies work is described. The importance of local studies aspect in education, ideas and activity of prominent Ukrainian educators is analyzed. Musical studies is considered as a scientific branch and academic discipline of higher education institution. The content and tasks of academic course "Musical art of Rivne region", its relevance and usefulness of implementation in student training of all art specialities are revealed. Public and international documents of support and achievement of local studies development in Ukraine, especially art local studies is the key to its successful development.

\section{REFERENCES}

1. Анікіна Т.О., Таран Н.С. Науково-історичні передумови використання художнього краєзнавства у вихованні патріотизму. Педагогіка і психологія. 1995. № 4. С. 98-105.

2. Асафьев Б.В. Русская музыка XIX и начала XX века. 2-е изд. Ленинград, 1979. 340 с.

3. Бех І.Д., Чорна К.І. Національна ідея в становленні громадянина-патріота України: (Програмно-виховний контекст). Черкаси, 2010. 40 с.

4. Ващенко Г. Виховний ідеал. Полтава : Полтавський вісник, 1994. $191 \mathrm{c}$.

5. Губ'як В.Д. Виховання учнів на засадах народної творчості і фольклору. Рідна школа. 1999. № 11. С. 9-11. 
6. Державна програма «Повернуті імена» : Нац. комісія з питань повернення в Україну культурних цінностей. Київ : ООО «Танант», 1996. $26 \mathrm{c.}$

7. Дикало В. Музичне краєзнавство Рівненщини як навчальний курс: до постановки проблеми. Нова педагогічна думка : наук.метод. журнал. 2016. № 2(86). С. 124-128.

8. Иванов П.В. Педагогические основы школьного краеведения. Петрозаводск : Карел, 1966. 182 с.

9. Знаменні та пам'ятні дати 2015 року : мистецько-освітній довідник / упоряд. В.І. Дикало, М.Ф. Смалько, Л.П. Яковенко ; за ред. В.І. Дикало. Рівне : О. Зень, 2015. 76 с.

10.Калиниченко Н.П., Копиленко Н.Б. Софія Русова. Рідна школа. 1991. № 12. С. 69-72.

11.Конвенція про охорону нематеріальної культурної спадщини від 06.03.2008 p. № 132-VI. URL : https://zakon.rada.gov.ua/laws/ show/995_d69 (дата звернення 15.02.2020).

12.Конвенція про охорону та заохочення розмаїття форм культурного самовираження. Ратифіковано Законом України від 20.01.2010 p. № 1811-VI. URL : http://zakon0.rada.gov.ua/laws/ show/952_008 (дата звернення: 15.02.2020).

13.Концепція та комплексна програма художньо-естетичного виховання у загальноосвітніх та позашкільних навчальних закладах : Інформ. збірник $\mathrm{M}$-ва освіти i науки України / Л.М. Масол, Н.І. Ганнусенко, О.А. Комаровська, С.А. Ничкало та ін. Київ : Пед. преса, 2004. № 10. 32 с.

14.Мала енциклопедія етнодержавознавства / ред. кол.: Ю.І. Римаренко (відп. ред.) та ін. Київ : Довіра : Генеза, 1996. 942 с.

15.Молодіжні трудові загони відродять Батурин, Бахчисарай та Хортицю: Урядовий портал. URL : http://old.kmu.gov.ua/kmu/ control/uk/publish/printable_article?art_id=140533446 (дата звернення 15.02.2020).

16. Морітз Я. Система професійної підготовки вчителя і шляхи ії оптимізації в умовах розвитку сучасної освіти в Польщі : автореф. дис. ... док. пед. наук : 13.00.04. Київ, 2004. 41 с.

17.Національна спілка краєзнавців України. URL : http://nsku.org.ua/?page_id=5610 (дата звернення: 15.02.2020).

18. Основи національного виховання: концептуальні положення / В.Г. Кузь, Ю.Д. Руденко, 3.О. Сергійчук та ін. Умань, 1993. 112 с.

19.Педагогічний словник / за ред. М.Д. Яремченка. Київ : Педагогічна думка, 2001. 321 с.

20.Перспективи розвитку краєзнавчого руху: пропозиції до проекту Державної програми розвитку краєзнавства на період до 
2025 p. URL : http://history.org.ua/JournALL/kraj/kraj_2013_1/2.pdf (дата звернення 15.02.2020).

21.Про деякі невідкладні заходи щодо підтримки культури і духовності в Україні : Указ Президента України від 12.01.2009 р. № 6/2009. URL : https://zakon1.rada.gov.ua/cgi-bin/laws/main.cgi $? \mathrm{nreg}=6 \% 2 \mathrm{~F} 2009 \& \mathrm{p}=1287560658798567$ (дата звернення: 25.01.2020).

22.Про затвердження Концепції національно-патріотичного виховання дітей і молоді, Заходів щодо реалізації Концепції національно-патріотичного виховання дітей і молоді та методичних рекомендацій щодо національно-патріотичного виховання у загальноосвітніх навчальних закладах : Наказ МОН України від 16.06.2015 p. № 641. URL : http://osvita.ua/legislation/Ser_osv/47154/ (дата звернення 25.01.2020).

23.Про затвердження Міжгалузевої програми «Пізнай свою країну» на 2007-2012 роки : Наказ Міністерства культури і туризму України, Міністерства освіти і науки України, Міністерства України у справах сім'ї, молоді та спорту, Державного комітету телебачення та радіомовлення України від 27.08.2007 р. № 49/765/3027/308. URL : $\quad$ https://zakon.rada.gov.ua/rada/show/v0049655-07/sp:max15 (дата звернення 15.02.2020).

24. Про затвердження Програми розвитку краєзнавства на період до 2010 року: Постанова КМУ від 10.06 .2002 р. № 789. URL : http://zakon4.rada.gov.ua/laws/show/789-2002-\%D0\%BF (дата звернення 15.02.2020).

25.Про заходи щодо відтворення видатних пам'яток історії та культури : Указ Президента України від 9.12.1995 р. № 1138/95. URL : https://zakon.rada.gov.ua/laws/show/1138/95 (дата звернення 25.01.2020).

26.Про заходи щодо підтримки краєзнавчого руху в Україні : Указ Президента України від 23.01.2001 р. № 35/2001. URL : http://zakon2.rada.gov.ua/laws/show/35/2001 (дата звернення: 25.01.2020).

27.Прокопчук (Дикало) В.I. Законодавче забезпечення розвитку мистецького краєзнавства в Україні. Нова педагогічна думка : наук.метод. журнал. Рівне : РОІППО, 2019. № 4 (100). С. 181-185. DOI: 10.37026/2520-6427-2019-100-4-181-185.

28. Прокопчук (Дикало) В.І. Мистецьке краєзнавство як науковопедагогічна проблема. Інноватика у вихованні: зб. наук. праџь / упоряд. О.Б. Петренко ; ред. кол. : О.Б. Петренко, Р.Л. Сойчук, T.C. Ціпан та ін. Рівне : РДГУ, 2019. Випуск 10. С. 226-233. DOI: 10.35619/iiu.v1i10.189. 
29.Прокопчук (Дикало) B.I. Мистецьке краєзнавство як чинник національно-патріотичного виховання майбутніх педагогів. Молодь $i$ ринок: щомісячний науково-педагогічний журнал. Дрогобич: Дрогобицький держ. педагог. університет ім. І. Франка, 2019. № 12 (179). $\quad$ C. 64-69. DOI: https://doi.org/10.24919/23084634.2019.193520.

30.Про Національну стратегію розвитку освіти в Україні на період до 2021 року: Указ Президента України від 25.06.2013 р. № 344/2013. URL : http://zakon3.rada.gov.ua/laws/show/344/2013 (дата звернення: 15.02.2020).

31.Про освіту : Закон України від 16.01 .2020 р. № 2145-VIII. URL : https://zakon.rada.gov.ua/laws/show/2145-19 (дата звернення: 15.02.2020).

32.Рудницька О.П. Педагогіка: загальна та мистецька : навчальний посібник. Тернопіль : Навчальна книга - Богдан, 2005. $360 \mathrm{c}$.

33.Стельмахович М.Г. Народна педагогіка. Київ : Радянська школа, 1985. $321 \mathrm{c}$.

34.Сухомлинський В.О. Сто порад учителеві: Вибрані твори : у 5 т. Київ, 1976. Т. 2. С. 419-655.

35.Тронько П.Т. Історичне краєзнавство: Крок у нове тисячоліття (Досвід. Проблеми. Перспективи). Київ, 2000. 270 с.

36. Ушинський К.Д. Твори в 6-ти томах. Київ : Радянська школа, 1995. Т. 6. С. $562-566$.

37.Шамрай О.Г. Роль краєзнавства у навчально-виховному процесі. Педагогічний вісник, 2002. № 4. С. 73-75.

38.Этингер М. Внимание к музыкальному краеведению. Советская музыка. 1983. № 1. С. 99-102.

39. Юцевич Ю.С. Музика. Словник-довідник. Тернопіль : Навчальна книга - Богдан, 2003. 352 с.

\section{Information about author: Prokopchuk V. I.,}

Candidate of Pedagogical Sciences, Associate Professor at the Department of Playing Musical Instruments Institutes of Arts of the Rivne State University of Humanities 12, Stephan Bandera Str., Rivne, Ukraine 